\title{
CARTA DO COMITÊ EDITORIAL
}

O avanço da vacinação contra a covid-19 trouxe alívio para as nossas sociedades, e hoje vemos que pela primeira vez nove estados brasileiros registraram um dia sem mortes ${ }^{1}$ por esta doença que já ceifou mais de 610 mil vidas brasileiras. No entanto, ainda são tempos difíceis. São quase dois anos de um contexto pandêmico que não acabou de todo, mas que já deixou inúmeras consequências para o Brasil e para o mundo. Levaremos as cicatrizes desse triste episódio da nossa história por muitas décadas.

O luto, a solidão, a ansiedade pelo futuro e o cansaço generalizado nos levam a sentir as consequências psicológicas deste período pandêmico. Afinal, para muitos de nós a vida mudou. É trabalho em home office, é ser professor dos filhos em casa, é cuidar de um ser amado acometido pela covid-19. Um verdadeiro acúmulo de funções.

Concomitante aos desafios do contexto sanitário, o Brasil vive uma crise política, econômica e institucional. A miséria e o desemprego se ampliaram tanto que o Brasil voltou ao mapa da fome ${ }^{2}$. São retrocessos de todos os lados. $\mathrm{Na}$ área da educação e pesquisa, por exemplo, fomos surpreendidos com um corte de $92 \%$ no orçamento de 2022 destinado ao Ministério da Ciência e Tecnologia. E como este número é dedicado a um dossiê voltado às questões ambientais não podemos deixar de destacar que, de acordo com dados levantados pela BBC News Brasiß, o governo

\footnotetext{
${ }^{1}$ PORTO, Douglas; CATACCI, Mariana. Nove estados não registram mortes por Covid-19 nas últimas 24 horas https://www.cnnbrasil.com.br/saude/nove-estados-nao-registrammortes-por-covid-19-nas-ultimas-24-horas/. CNN, 08 de novembro de 2021. Acesso em: 09 de novembro de 2021.

${ }^{2}$ GUIMARÃES, José. Com Bolsonaro, o Brasil voltou ao mapa da fome. Carta Capital, 15 de julho de 2021. Disponível em: https://www.cartacapital.com.br/opiniao/frente-ampla/combolsonaro-o-brasil-voltou-ao-mapa-da-fome/. Acesso em: 09 de novembro de 2021.

${ }^{3}$ PRAZERES, Leandro. Brasil cortou $93 \%$ da verba para pesquisa em Mudanças Climáticas, Bbc News Brasil, 03 de novembro de 2021. Disponível em: https://g1.globo.com/meio-ambiente/
} 
do presidente Jair Bolsonaro cortou em 93\% a verba para pesquisas sobre mitigação e adaptação às mudanças climáticas nos três primeiros anos da sua gestão quando comparado com os três anos anteriores.

O contexto sanitário, social, econômico e político afeta todas as esferas da vida, e o trabalho acadêmico não é uma exceção. No dossiê Prática Médicas e Terapêuticas (n. 55) já havíamos sinalizado as dificuldades da produção acadêmica em tempos de pandemia. No dossiê Interpretações do Brasil e dilemas contemporâneos (n. 57) destacamos as dificuldades do nosso trabalho de editoração, tanto de encontrar pareceristas quanto do baixo número de submissões realizadas por mulheres.

Durante a produção deste dossiê (n. 58) tivemos novos agravantes. Ainda que com o significativo avanço da vacinação nos meses mais recentes, a exaustão, o sobrecargo de funções e todas as questões psicológicas decorrentes do contexto atual estão potencializadas. Não por acaso o número de submissões caiu, e nos deparamos com uma situação raramente vista na história da Temáticas, em que autores desistiram do processo de publicação de textos aprovados - o que é compreensível, visto que o processo editorial é longo e exigente.

Diante disso, estamos orgulhosos em dizer que mesmo em meio a tantos obstáculos conseguimos produzir um dossiê instigante, organizado por Tathiane Mayumi Anazawa, Kelly Cristina de Moraes Camargo, Augusto Frederico Junqueira Schmidt e Roberto Luiz do Carmo, e o apresentamos junto de dois artigos na sessão livre: "As ganhadeiras de Itapuã: uma etnografia de um ensaio de uma escola de samba no centro de Niterói- RJ", escrito por Rafael Rosa da Silva, e "Paranismo, NeoParanismo e as mídias sociais: um estudo dos símbolos paranaenses na gestão Greca a partir do Facebook (2016-2021)", assinado por Bárbara Fonseca.

Destacamos, por fim, que o dossiê Processos, conflitos e desafios: as questões ambientais pela perspectiva das Ciências Sociais está composto por quatro artigos e uma entrevista. O primeiro artigo reflete sobre a bioética global no processo de manipulação genética na agropecuária. O segundo texto

cop-26/noticia/2021/11/03/brasil-cortou-93-da-verba-para-pesquisa-em-mudancasclimaticas.ghtml. Acesso em: 09 de novembro de 2021. 
discute o termo sustentabilidade, focando-se na sustentabilidade urbana em área de Floresta Amazônica. O terceiro artigo analisa as escolhas alimentares de consumidores de orgânicos de uma feira livre. E o quarto artigo faz uma reflexão sobre um estudo de caso de migração do urbano com destino ao rural, realizada por grupos da classe média. Compõe ainda o dossiê uma entrevista com a professora Heloísa Costa (UFMG), na qual discutimos as articulações entre a dimensão ambiental e o planejamento urbano.

A professora Costa nos deixou uma mensagem de otimismo e esperança ao dizer que a palavra do momento deve ser (re)construção. Finalizar mais um dossiê nesses tempos de pandemia e crise institucional é nossa contribuição para a construção do futuro que queremos. Um futuro mais ambiental e socialmente sustentável. E, desse modo, agradecemos a todos os envolvidos no desenvolvimento desse número: os autores, pareceristas, editores e organizadores. Expressamos também nossos desejos de que possamos reconstruir juntos os sonhos perdidos, porque amanhã vai ser outro dia.

Comitê Editorial, novembro de 2021. 